\title{
Extravascular Matrix Loops
}

National Cancer Institute

\section{Source}

National Cancer Institute. Extravascular Matrix Loops. NCI Thesaurus. Code C111025.

A microscopic finding indicating the presence or absence of extravascular matrix loops in uveal melanoma. 